\title{
Acute Renal Hypertrophy in Experimental Diabetes: Lack of Effect of Short-Term Growth Hormone Administration
}

\author{
K. Seyer-Hansen, H. J. G. Gundersen and R. Østerby \\ Second University Clinic of Internal Medicine, Institute of Experimental Clinical Research, and Department of Cell Biology, \\ Institute of Anatomy, Aarhus University, Denmark
}

Summary. Normal and diabetic rats were given daily injections of human growth hormone for four days (5 mg per rat per day). Injected rats showed no differences from uninjected controls with respect to kidney weight or renal content of protein, RNA or DNA. Kidney weight increased by $7 \%$ after two days of diabetes and by $20 \%$ after four days, but growth hormone caused no augmentation of the hypertrophy. It is concluded that growth hormone plays no role in the initiation of diabetic renal hypertrophy.

Key words: Diabetes, growth hormone, hypertrophy, kidney, rat, streptozotocin.

It is well established that early diabetes is accompanied by renal hypertrophy, both in man [1] and in experimental animals [2]. The mechanism by which the kidney growth is initiated is, however, unknown. Plasma growth hormone $(\mathrm{GH})$ is elevated in diabetic man [3], and it has been suggested that the increased kidney size and function could be an effect of the high level of circulating GH [4], the renal hypertrophy thus being similar to that seen in acromegaly. The present study was undertaken to test this hypothesis.

\section{Methods}

Female Wistar rats weighing $175 \pm 15 \mathrm{~g}$ were used. They were housed three per cage and had free access to food and water. Diabetes was induced by IP injection of streptozotocin dissolved in saline ( $\mathrm{pH}$ adjusted to 4.7 by addition of $\mathrm{HCl}$ ). The dose was $55 \mathrm{mg}$ / $\mathrm{kg}$. Only animals with a blood glucose concentration above $17 \mathrm{mmol} / 1$ at the end of the experiment were included in the study.

Five groups of rats were studied: (A) rats with diabetes for 2 days (i. e. they were killed $48 \mathrm{~h}$ after administration of streptozoto- cin); (B) rats with diabetes for 4 days; (C) diabetic rats, who received GH injections for 4 days, beginning on the day of streptozotocin; (D) normal rats given GH for 4 days; (E) untreated control rats. Growth hormone (human growth hormone, Nanormon, Nordisk Insulin) was given as daily SC injections of $5 \mathrm{mg}$. Blood glucose (Ames Reflectance Meter) and body weight were measured every second day.

At the end of the experimental period the rats were anaesthetised with pentobarbital $(25 \mathrm{mg} / \mathrm{kg})$ and diazepam $(10 \mathrm{mg} / \mathrm{kg})$, and the right kidney was removed after ligation of the renal pedicle and stored in the frozen state until further processing as previously described [2]. RNA was measured by ultraviolet spectrophotometry [5], DNA with diphenylamine [6], and protein according to Lowry et al. [7].

Results in the tables are given as mean \pm SD. Body weights were compared by use of a paired Student's t-test.

\section{Results}

The injected GH promoted growth, both in normal and in diabetic rats (Table 1 and Fig. 1). In the latter group the initial loss in body weight seen in the first 2 days of diabetes was reversed. Table 2 demonstrates that GH had no effect on kidney weight, protein, RNA or DNA content. The diabetic hypertrophy previously described was clearly seen, but it was not augmented by GH administration. The dose of GH employed had no effect on the blood glucose level.

\section{Discussion}

The results show that human GH in biologically potent doses had no effect on kidney size in the rat when given for 4 days. This is in accordance with a report by Bates and Garrison [8], who found no effect on kidney weight in rats by bovine $\mathrm{GH}$ in a dose of $5 \mathrm{mg}$ /day for

Table 1. Body weights (g) of rats in different treatment groups (mean \pm SD)

\begin{tabular}{|c|c|c|c|c|c|c|}
\hline & \multirow[t]{2}{*}{ No. of rats } & \multicolumn{3}{|c|}{ Duration of GH treatment (days) } & \multicolumn{2}{|c|}{ Significance of differences $(2 p)$} \\
\hline & & 0 & 2 & 4 & $\begin{array}{l}0 \text { versus } 2 \\
\text { days }\end{array}$ & $\begin{array}{l}2 \text { versus } 4 \\
\text { days }\end{array}$ \\
\hline Control & 11 & $175 \pm 8.1$ & $181 \pm 8.1$ & $183 \pm 8.2$ & $<0.005$ & $<0.01$ \\
\hline Control $+\mathrm{GH}$ & 11 & $177 \pm 10.2$ & $183 \pm 11.7$ & $190 \pm 12.6$ & $<0.001$ & $<0.001$ \\
\hline Diabetes & 11 & $177 \pm 9.5$ & $168 \pm 9.9$ & $170 \pm 10.2$ & $<0.001$ & $>0.05$ \\
\hline Diabetes $+\mathrm{GH}$ & 11 & $172 \pm 9.9$ & $166 \pm 10.0$ & $171 \pm 12.6$ & $<0.001$ & $<0.02$ \\
\hline
\end{tabular}


Table 2. Kidney weight and content of protein, RNA and DNA of rats in different treatment groups

\begin{tabular}{|c|c|c|c|c|c|c|c|c|c|}
\hline & \multirow{2}{*}{$\begin{array}{l}\text { No. } \\
\text { of } \\
\text { rats }\end{array}$} & \multirow{2}{*}{$\begin{array}{l}\text { Final blood } \\
\text { glucose } \\
(\mathrm{mmol} / 1)\end{array}$} & \multicolumn{2}{|c|}{ Kidney weight } & \multirow{2}{*}{$\begin{array}{l}\text { Protein } \\
\text { (mg) }\end{array}$} & \multirow[t]{2}{*}{ RNA (mg) } & \multirow[t]{2}{*}{ DNA (mg) } & \multirow{2}{*}{$\begin{array}{l}\text { Protein/ } \\
\text { DNA }\end{array}$} & \multirow[t]{2}{*}{ RNA/DNA } \\
\hline & & & $(\mathrm{mg})$ & $\begin{array}{l}\text { (\% body } \\
\text { weight) }\end{array}$ & & & & & \\
\hline Control & 10 & $4.9 \pm 0.3$ & $710 \pm 44$ & $3.9 \pm 0.3$ & $84 \pm 4$ & $2.86 \pm 0.15$ & $3.54 \pm 0.19$ & $23.7 \pm 1.6$ & $0.81 \pm 0.06$ \\
\hline $\begin{array}{l}\text { Control }+ \\
\text { GH }\end{array}$ & 9 & $5.0 \pm 0.2$ & $726 \pm 96$ & $3.8 \pm 0.4$ & $86 \pm 9$ & $2.83 \pm 0.29$ & $3.58 \pm 0.53$ & $24.5 \pm 2.1$ & $0.80 \pm 0.06$ \\
\hline $\begin{array}{l}\text { Diabetes for } \\
2 \text { days }\end{array}$ & 13 & $19.8 \pm 2.3$ & $759 \pm 12$ & $4.3 \pm 0.3$ & $89 \pm 7$ & $3.06 \pm 0.18$ & $3.48 \pm 0.29$ & $25.8 \pm 1.9$ & $0.88 \pm 0.07$ \\
\hline $\begin{array}{l}\text { Diabetes for } \\
4 \text { days }\end{array}$ & 11 & $20.2 \pm 2.7$ & $854 \pm 92$ & $5.0 \pm 0.3$ & $98 \pm 6$ & $3.54 \pm 0.26$ & $3.70 \pm 0.43$ & $26.8 \pm 2.4$ & $0.97 \pm 0.07$ \\
\hline $\begin{array}{l}\text { Diabetes for } \\
4 \text { days }+ \text { GH }\end{array}$ & 11 & $20.5 \pm 1.7$ & $860 \pm 76$ & $5.0 \pm 0.4$ & $97 \pm 10$ & $3.54 \pm 0.26$ & $3.71 \pm 0.45$ & $26.4 \pm 2.0$ & $0.96 \pm 0.07$ \\
\hline
\end{tabular}

Results are mean values \pm SD for one kidney.

No significant differences were found between control and control + GH or between diabetes for 4 days and diabctes for 4 days + GH

5 days. This lack of effect is probably due to the short experimental period, as rats with chronic GH hypersecretion (tumour bearing Wistar-Furth rats) do exhibit renal hypertrophy [9].

The suggestion that GH might initiate renal hypertrophy is based on the findings in rats with GH hypersecretion, on the correlation seen between elevated plasma GH and increased glomerular filtration rate in Type 1 (insulin dependent) diabetics [4] and on the observation that injections of GH increase renal plasma flow and glomerular filtration rate in man after 4-5 days [10]. It appears that kidney growth in rats with GH hypersecretion is a part of the general growth of the animal, relative kidney weight remaining unchanged [9]. This situation is different both from compensatory renal hypertrophy, where whole animal weight remains unchanged, and from diabetes where body weight actually decreases.

The modest increase in glomerular filtration rate seen after injections of GH to non-diabetic subjects probably is the result of haemodynamic changes (increased blood volume) and may not be related to the structural changes seen in the diabetic kidney.

Growth hormone thus seems to play no role in the development of acute renal hypertrophy in experimental diabetes. We have previously reported on an increased thickening of the peripheral glomerular basement membrane in diabetic rats treated with $\mathrm{GH}$ for 5 months [11]. However, by further extension of the experiments we have been unable to confirm this report. We have thus found no effect of exogenous GH on either short term or long term lesions in the diabetic rat.

Acknowledgements. This study was supported by the Danish Medical Research Council. Nanormon was a generous gift from Nordisk Insulin Laboratorium, Copenhagen. Mrs. Joan Hansen is thanked for excellent technical assistance.

\section{References}

1. Mogensen CE, Andersen MJF (1973) Increased kidney size and glomerular filtration rate in early juvenile diabetes. Diabetes 22: $706-712$

2. Seyer-Hansen K(1976) Renal hypertrophy in streptozotocin diabetic rats. Clin Sci Mol Med 51 : 551-555

3. Hansen AP (1972) Serum growth hormone patterns in juvenile diabetes. Dan Med Bull 19: 1-36

4. Hansen AP, Mogensen CE (1972) Growth hormone secretion

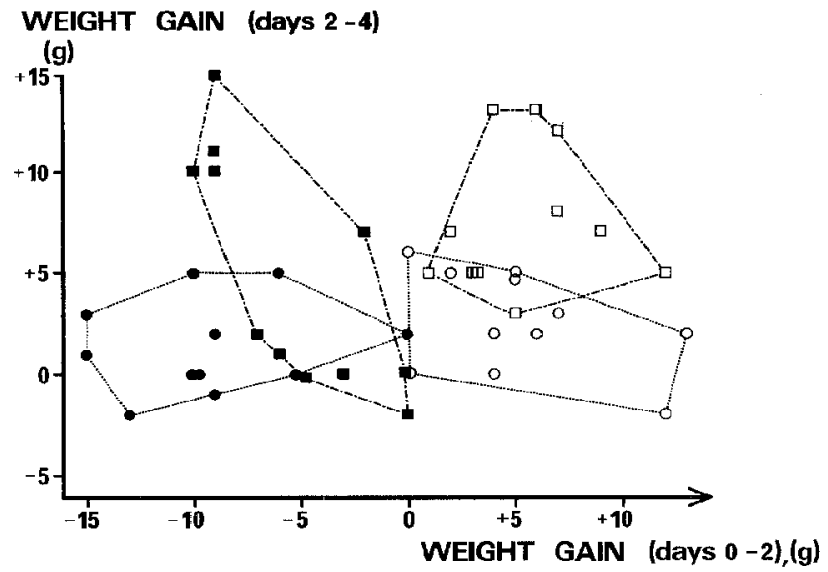

Fig. 1. Bidimensional plot of weight changes in normal rats $(O)$, growth hormone treated normal rats $(\square)$, streptozotocin diabetic rats (๑), and growth hormone treated diabetic rats $(\boldsymbol{E})$. The abscissa shows the increase in body weight from days $0-2$, the ordinate that from days $2-4$. The dotted lines are the minimal string polygones enclosing data from each group of animals

and kidney function during normalization of the metabolic state in untreated juvenile diabetes mellitus. Horm Metab Res 4: $11-15$

5. Munro HN, Fleck A (1966) The determination of nucleic acids. Methods Biochem Anal 14:113-176

6. Burton K (1956) A study of the conditions and mechanism of the diphenylamine reaction for the colorimetric estimation of deoxyribonucleic acid. Biochem J 62:315-323

7. Lowry OH, Rosebrough NJ, Farr AL, Randall RJ (1951) Protein measurement with the Folin phenol reagent. J Biol Chem 193:265-275

8. Bates RW, Garrison MM (1974) Hormonal interactions among $\mathrm{GH}, \mathrm{ACTH}$, cortisol and dexamethasone upon size of kidney, liver, and adrenal. Proc Soc Exp Biol Med 146: 725-731

9. Åkerblom HK, Martin JM, Garay GL, Moscarello M (1972) Experimental hypersomatotropism. II. Metabolic effects in rats bearing the MtT-W15 tumor. Horm Metab Res 4: 15-21

10. Corvilain J, Abramow M, Bergans A (1962) Some effects of human growth hormone on renal hemodynamics and on tubular phosphate transport in man. J Clin Invest 41: 1230-1235

11. Østerby R, Seyer-Hansen K, Gundersen HJG, Lundbæk K (1978) Growth hormone enhances basement membrane thickening in experimental diabetes. A preliminary report. Diabetologia 15:487-489

Received in revised form: 12 June 1981

K. Seyer-Hansen

Medical Department M

Svendborg Sygehus

DK-5700 Svendborg, Denmark 